\title{
Tides as drivers of plates and criticism of mantle convection
}

\author{
L. Ostřrihanský
}

Received: 24 May 2014 / Accepted: 3 November 2014 / Published online: 16 January 2015

(C) Akadémiai Kiadó 2014

\begin{abstract}
Forces moving plates are of two kinds: Force moving plates to the north and force moving plates to the west. They are both, by their origin, related to tidal forces but they act in quite different way. The northward force acts by its center in meridian, the westward force acts in direction of geographic parallels. Tidal forces of semidiurnal and diurnal periods cannot move plates because triggering of earthquakes by the stress of these amplitudes gives statistically insignificant results confirmed by many reports for more than 100 years. However the tidal forces acting on $10 \mathrm{~km}$ Earth's rotation bulges and the periodic Earth's deformations resulting in Earth's rotation variations give strong forces energetically equivalent to energy of large earthquakes. Oceanic lithosphere older than 180 M.Y. drops down to the mantle by gravity or is liquidated being overridden beneath continent. At that movement the released space facilitates the plate movement by tides. Hotspots firmly anchored in mantle show by tracks an exact movement of plates. Mantle convection is disregarded because it contradicts to existence of mid-ocean ridges triple junctions. Not Polfluchtkraft but Äquatorkraft force the tides create, which can move the large continent (for example Gondwana) far from equator as far as the pole, where after decay the Antarctica remains being out of tidal forces actions.
\end{abstract}

Keywords Lithospheric plates movement · Tidal forces · Earth's rotation ·

No mantle convection

\section{Introduction}

To recognize forces acting on the lithosphere scientists tried to estimate for very long time. I will not deal with a long history of this investigation because most results of these investigations are based on mistakes and these mistakes are persistent to the present time. However there are recognized phenomena which cannot be disproved. Recognized coastal fit of

L. Ostřihanský is a pensioner.

L. Ostřihanský (ه)

National Library of the Czech Republic, Klementinum 190, 11000 Prague 1, Czech Republic e-mail: ostrih@tiscali.cz 
separated continents proves that continents move. Already 1,526 Abraham Ortelius in his Thesaurus Geographicus discussed continental congruity of the Old and New Worlds. Vertical movements of continents are ruled by Archimedes law, in geophysics expressed by the term of isostasy according to model of Pratt (1855) and Airy (1855). A. D. Kreichgauer in his book (1902) Die Äquatorfrage in der Geologie submitted idea of equatorward force of crustal motion which would product fold belts aligned along equator while a second set of tectonomagmatic belts he recognized in meridional settings (i.e., orthogonal to equator) owing to westward directed tidal drag from the Sun and Moon. This undoubtedly correct recognition of orthogonal tectonomagmatic belts has one drawback: such belts should stay permanently on equator. This requires imagination of polar wander resulting in equator change position in Earth's history deeply elaborated in K.M. Storetvedt's book (2003) Global wrench tectonics. It is probable that during Archaic or Proterozoic polar wander existed and Storetvedt (ibid) presents many convincing proofs of it. Alfred Wegener (1912, 1915, 1929) was convinced that continents move but gave credit to Kreichgauer of westward force driven by tides and the equatorward force which he named pole-fleeing force, later named as the Eötvös (1913) force. Acording to author's calculations (Ostřihanský 1997, 2004), maximum torque of this force is only $10^{13} \mathrm{~N} \mathrm{~m}$. In addition to it, continents driven by the Eötvös force remain permanently on equator. To avoid this, the polar wander was required confirmed by paleoclimatic changes on continents. Doubts can be cast on it because for example in Carboniferous (better term is Permo-Carboniferous) raised temperature existed over the whole Earth, extreme evaporation in oceans caused extreme humidity suitable for vast forests growing in higher latitudes and wide spread coal deposits over the world. In the last edition of Wegener's "Origin of continents and oceans" (1929) Wegener devaluated his work considering mantle convection as the plate drivers. Dietz (1961), Hess (1962), Wilson (1965) and others presented hypothesis that oceanic lithosphere is created by sea-floor spreading in mid-ocean ridges and extincts dropping down to mantle in subduction zones with mantle convection as driving force. This evoked strong resistance of Storetvedt (1997, 2003) claiming impossibility of such mechanism owing to existence of continental lithosphere remnants in middle of large oceans e.g., in Indian Ocean and existence of non-basaltic igneous rocks as serpentinites and other metamorphic rocks in mid-ocean ridges of the same types as can be found in mobile belts. If existence of mantle convection is disproved then mid-ocean ridges move over oceans with the speed of adjacent plates, such rocks can be encountered by moving mid-ocean ridges coming from subduction zones or to be remnants of ancient oceans destroyed by meteoritic bombardment being situated in shallow depth below oceanic lithosphere. The last mistake from recent time is supposing that GPS determine the real movements of lithospheric plates. The satellite GPS system, firmly situated in space and bound on Earth's surface, says nothing about the plate movement over mantle, only short time movements during earthquakes show real direction and size of the movement (Ostřihanský 2012a).

To estimate real causes of the plate movements it is necessary to proceed in following steps:

(1) To disprove existence of convection in mantle as the plate driver.

(2) To calculate tidal forces acting on plates and to prove that they are sufficiently strong to move plates.

(3) To prove that lithospheric plates move in directions of tidal forces action. The best tool for it are hotspot tracks, which situated in mantle and not disturbed by mantle convection, and if situated further from mid-ocean ridge, reliably determine direction of the plate movement. 
(4) To prove that largest earthquakes are triggered in maximum tidal forces actions confirming origin of forces. To prove that earthquakes are repeated when position of Earth, Moon and Sun is repeated in 19 years Metonic cycle or in multiple of 19 years period.

Acceptance of the plate tectonics revitalized an imagination about tidal forces plate drivers starting with Bostrom (1971), Knopoff and Leeds (1972) and Moore (1973). Geological and geophysical community accepted mantle convection as plate driver considering the Earth as thermal engine. The greatest handicap of the mantle convection is the impossible explanation of triple points (crossings of mid-ocean ridges, very common among plates), i.e., existence of contemporarily acting convection cells situated perpendicularly or under certain angle. Possible explanation leads to imagination of the Earth's expansion as the next unfounded conjecture. For the first time the author presented his imagination that tides are drivers of plates in his Cand. Sci. Thesis (Ostřihanský 1978) and internationally in XX. GA IUGG in Vienna 1991 (Ostřihanský 1991). In 1997 the autor presented monograph: "The causes of lithospheric plates movements" (Ostřihanský 1997), which has almost identical results with the paper of Riguzzi et al. (2009). As far as statistically significant correlations between earthquakes and semidiurnal tides (Tanaka and co-workers 2004), (Cochran et al. 2004) or biweekly tides (Stavinschi and Souchay 2003), (Ostřihanský 2012a) were found, then in Riguzzi et al. (2009) tides are considered as factor only supporting mantle convection. The subject of this paper is to show, which kind of tidal forces is strong enough to move plates and whether plates really move in directions given by tidal forces. The paper is a continuation of papers (Ostřihanský 2012a,b), presenting statistics of earthquakes from continental and oceanic areas of the world. This paper explains in more detail mechanisms of the plate movements and calculation of forces acting on plates.

\section{Triple junctions phenomena exclude mantle convection}

Triple junctions of three mid-ocean ridges exclude existence of convection in the mantle. Considering mantle convection then every mid-ocean ridge has two convection currants bilaterally acting to both sides of the mid-ocean ridge pushing plates apart. If three midocean ridges intersect in one point then convection currents from adjacent mid-ocean ridges join in one stream directing from point of intersection (Fig. 1). Created streams rupture mid-ocean ridges apart and finish the triple junction existence.

Expansionists introduce useless complication to this problem. They consider fractures intersecting the mid-ocean ridge as trajectories of the plate movement. This is absolutely incorrect imagination. Position of the mid-ocean ridge is given by complicated movement of adjacent plates. Considering the Antarctic plate as stable on the South Pole then the Southeast

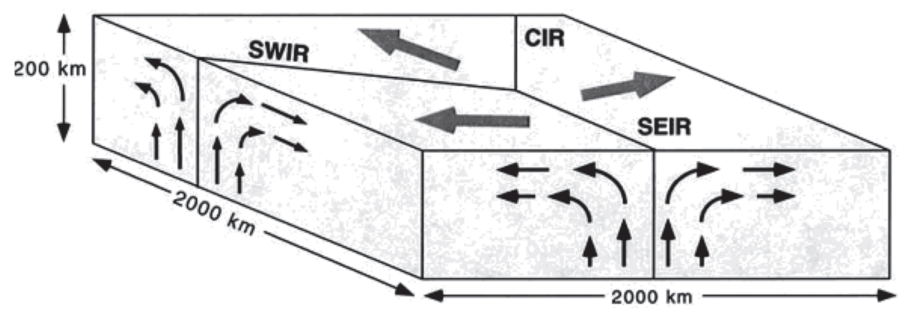

Fig. 1 Depicts the rupture of the triple junction by streams in direction of arrows 


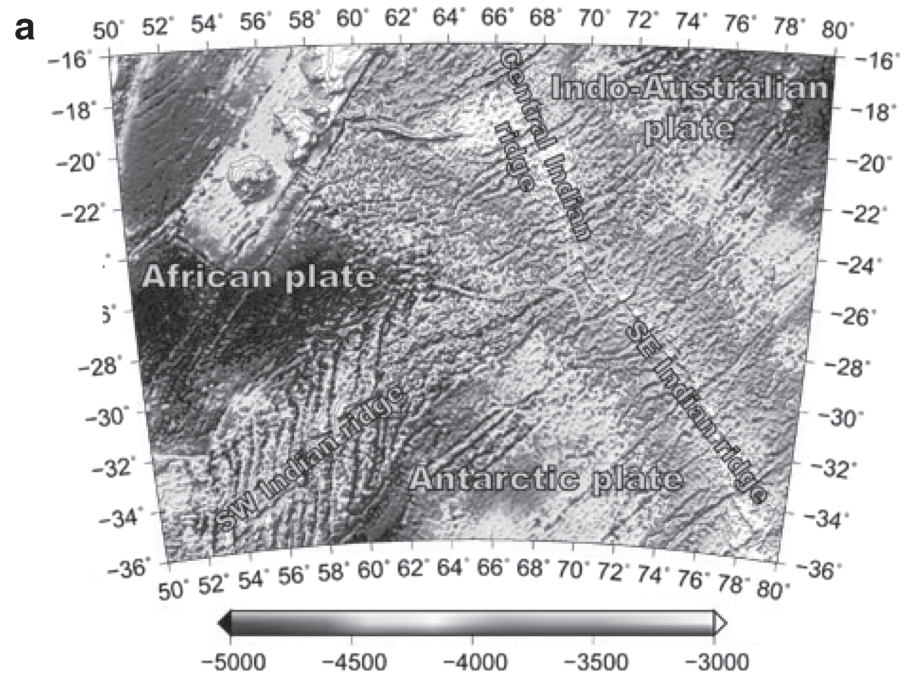

b

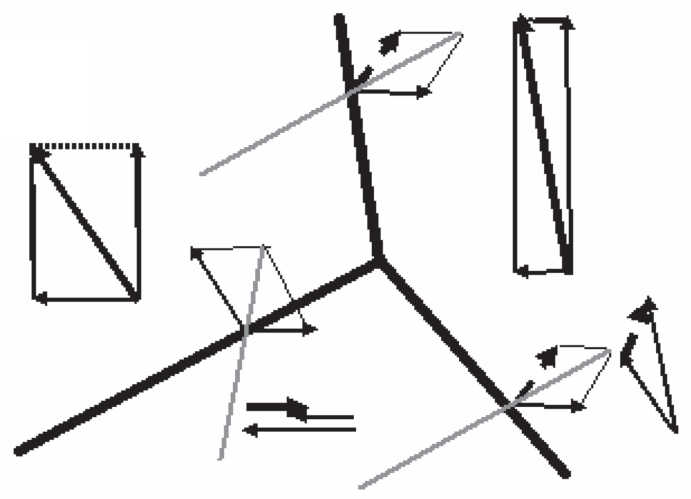

Fig. 2 a Rodriguez triple junction in the Indian Ocean separating African, Indo Australian and Antarctic plates by SW Indian, SE Indian and Central Indian Ocean ridges. Considering fractures intersecting mid-ocean ridges as trajectories of the plate movement then e.g., the African plate has paradoxically two Euler's poles of the plate rotation. b Gives explanation. Every plate has two components of its movement: the westward and northward. The African plate moves westward and northward, the Indo Australian plate moves less distinctively westward but strongly northward. The Antarctic plate has no northward components because is firmly fixed on the South Pole. It moves only eastward by difference between westward components of African end Indo Australian plates. Because the Antarctic plate has no northward components the SW Indian and SE Indian Ocean ridges move with 1/2 speed of African and Indo Australian plates. The direction of fractures intersecting mid-ocean ridges (marked by straight lines) are resultant of $1 / 2$ plate speed and vectorial difference speed of adjacent plates

and Southwest Indian Ocean ridges move with 1/2 speed of the Indo Australian and African plates and the directions of fractures crossing the mid-ocean ridge is given by vectorial subtraction of adjacent plates (on Fig. 2b marked by straight lines). Expansionists according to Fig. 2a consider e.g., African plate as manifested by two Euler's poles of rotation and use this argument for rejection of the plate tectonic theory. They present incorrect cartoon (Fig. 3) 


\section{Pole AB}

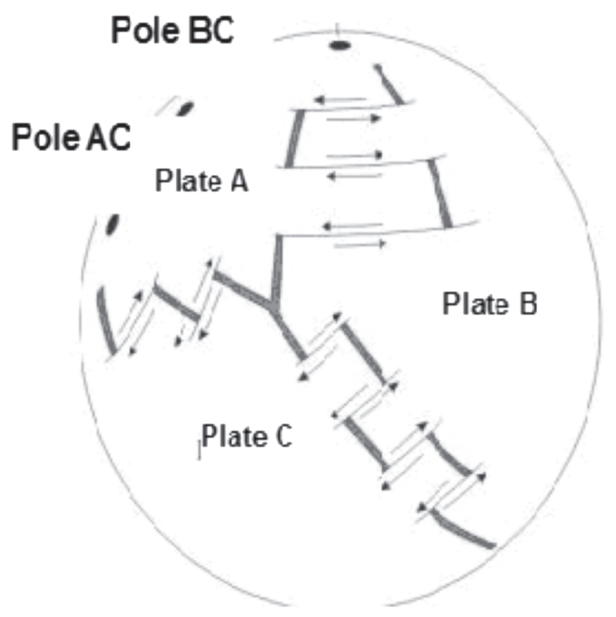

Pole AB

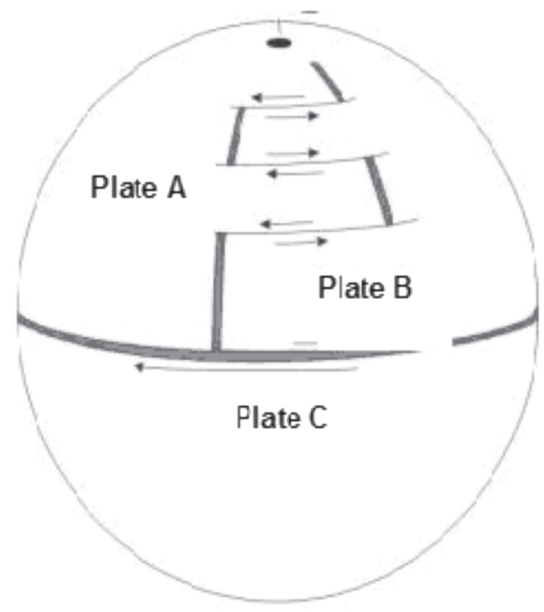

Fig. 3 Left paradox of the triple junction according to Scalera (2003). It presents incorrect cartoon with two Euler's poles for one plate created on both sides of mid-ocean ridge. Right depicts the movement of one plate separated by mid-ocean ridge and long transform fault, phenomenon very common in non-convecting mantle of the earth e.g., in eastern side of the Pacific Ocean

with two Euler's poles for one plate created on both sides of mid-ocean ridge (Fig. 3 left). On the other hand the right side of their cartoon is correct (Fig. 3 right) which depicts the movement of one plate separated by mid-ocean ridge and long transform fault, phenomenon very common in non-convecting mantle of the Earth, e.g. in eastern side of the Pacific Ocean.

Figure $2 \mathrm{~b}$ shows that every plate has its own movement given by forces that act on it and not by a speculative traction of convection cell below it. In case of convection, fractures intersecting the mid-ocean ridges were trajectories of the plate movement. Because this is not the case and fractures intersecting mid-ocean ridges are resultants of the movements of adjacent plates, this result definitely discards any imagination of the mantle convection driving plates.

\section{Calculation of forces driving plates}

Forces acting on plates can be easily calculated. They are of two kinds: Force acting to the north-south and force acting to the west. They are both, by their origin, related to tidal forces but they act in quite different way. The north-southward force acts by its center in meridian, the westward force acts in direction of geographic parallels. Remaining question is why at present time moving plates have only northward and westward components. The answer is that at present time sufficient continental area for subduction is only on the Northern Hemisphere. From this follows that the movement of plates by tidal forces is bound to subduction, which is a passive process of liquidation of oceanic lithosphere. Because oceanic lithosphere older than 180 M.Y. drops down by gravity to mantle, facilitates by this way the movement of created oceanic lithosphere or the movement of continents overriding it, in some cases including the mid-ocean ridge (East Pacific Rise). Continents therefore continue to consume the young oceanic lithosphere. 


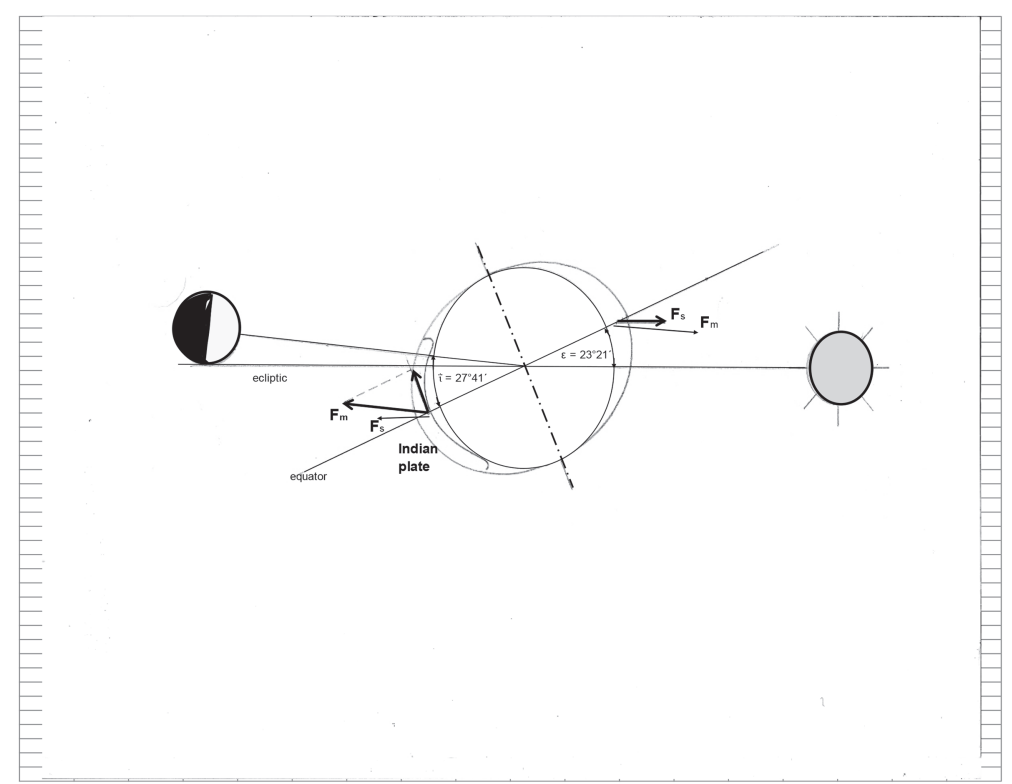

Fig. 4 Positron of Moon, Earth and Sun during the earthquakes M 6.6, of 27th. December 1985 and the Great Sumatra Earthquake of M 9.1, 26th. December 2004. Values of obliquity $\varepsilon=23^{\circ} 21^{\prime}$ and the Moon's tilt to equator $1=27^{\circ} 41^{\prime}$ concern of 2004 earthquake but they differ from 1985 earthquake negligibly. Fm and Fs are tidal forces of Moon and Sun acting on Earth's rotational flattening. Northward directing component of tidal force pushes the Indian plate northward out of equator (Äquatorfluchtkraft). After $1 / 2$ of solar day the tidal force acts in opposite direction against the mid-ocean ridge without any effect on the plate movement

Figure 4 shows the action of the northward force in its most effective action during the Sumatra earthquake 2004. The torque acting on the plate can be calculated in this configuration as torque acting in northern direction on the plate in $\mathbf{1 0} \mathbf{~ k m}$ bulging in Earth's rotational flattening. In this case the pull of the Moon is not caused directly by the Earth's tides but the tidal force rectifying the Earth's flattening to the plane of ecliptic and Moon's orbit. (Brož et al. 2011) present simple calculation of torque acting at that moment on the flattened lithosphere, i.e., on the Indian plate on configuration of Fig. 4.

Earth's angular velocity $\omega=7.2910^{-5} \mathrm{rad} / \mathrm{sec}$, Earth's moment of inertia $\mathrm{I}=8.07 \times$ $10^{37} \mathrm{~kg} \mathrm{~m}^{2}$ (Stacey 1977). Earth's angular momentum $\mathrm{L}=\mathrm{I} \times \omega=5.89 \times 10^{33} \mathrm{~kg} \mathrm{~m}^{2} \mathrm{~s}^{-1}$. Mass of the lithospheric bulge is

$$
m_{\text {bulge }}=\frac{1}{2}\left(\frac{4}{3} \pi a b c-\frac{4}{3} \pi c^{3}\right) \rho_{c r u s t},
$$

where we insert $a=b=R_{e} \approx 6,378 \mathrm{~km}, c=R_{e}-21 \mathrm{~km}, \rho_{\text {crust }} \approx 2,700 \mathrm{~kg} \mathrm{~m}^{-3}$ and we get $m_{\text {bulge }} \approx 9.6 \times 10^{21} \mathrm{~kg} \approx 1 / 624 m_{\mathrm{e}}$. (Earth's mass $m_{e}=5.9 \times 10^{24} \mathrm{~kg}$ ). The torque of force couple acting on the Earth is then: in case of the Sun $\left(m_{s}, r_{s}\right.$ Sun's mass and distance, G gravitational constant)

$$
M_{s}=2 \times \frac{2 G m_{\text {bulge }} m_{s}}{r_{s}^{3}} R_{e} \cos \varepsilon \cdot R_{e} \sin \varepsilon,
$$

where $\varepsilon=23.45^{\circ}$ is the obliquity of ecliptic to equator. This is valid only in case if the mass of bulge were concentrated in one point on equator and the Sun were just in highest point 
above equator. In reality we should integrate over the bulge because some its parts are closer to the axis of rotation and to center over the Earth's rotation because the instant angle of the Sun above equator varies. We would get:

$$
\bar{M}_{s}=\frac{1}{4} \mathrm{M}_{s} \approx 5.7 \times 10^{21} \mathrm{~N} \mathrm{~m}
$$

The same calculation is for the Moon:

$$
M_{m}=2 \times \frac{2 G m_{\mathrm{bu} \mathrm{lg}} m_{m}}{r_{m}^{3}} R_{e} \cos \iota \cdot R_{e} \sin \iota,
$$

where $\iota$ is the Moon's declination. The result is $\bar{M}_{m}=\frac{1}{4} M_{m} \approx 1.2 \times 10^{22} \mathrm{~N} \mathrm{~m}$. The torques simply sum up $\bar{M}=\bar{M}_{\mathrm{s}}+\bar{M}_{\mathrm{m}}=1.8 \times 10^{22} \mathrm{~N} \mathrm{~m}$.

This important result calculates that the torque $1.8 \times 10^{22} \mathrm{~N} \mathrm{~m}$ is able to move the plate. The seismic moment of the Sumatra earthquake is $3.5 \times 10^{22} \mathrm{~N} \mathrm{~m}$ (Varga and Denis 2010; Lay et al. 2005; Stein and Okal 2005). Because the torque exerted by tidal force acting on Earth's flattening represents the kinetic energy and also the seismic moment represents energy according to definition $\mathrm{M}_{0}=\mu \mathrm{AD}$, where $\mu$ is the shear modulus $\mathrm{N} / \mathrm{m}^{2}$, D is displacement on area $\mathrm{A}$, this quantity of $\mathrm{N}$ m dimension represents also energy, both quantities can be compared.

The tidal friction decelerates the Earth's rotation (Lambeck 1977) and therefore it can be also considered as the force causing the westward movement of plates. The torque exerted by tidal friction is relatively small $10^{16} \mathrm{~N} \mathrm{~m}$ (Burša 1987) and considering the mantle viscosity $10^{19} \mathrm{~Pa}$ s (Cathles 1975) only two orders of magnitude lower than the viscosity of lithosphere, this force is considered as insufficient for the plate movement. Today's mantle viscosity estimation following from the post glacial uplift, relative sea level changes and GRACE secular changes in gravity give relatively high values of upper mantle viscosity $5.3 \times 10^{20}$ Pa s (Paulson et al. 2007), which do not witness about easy movement of plates in mantle. Distinctive vertical movements however exist; they are caused by the mass accumulation by sedimentation or nappes compression in mountains and consequent melting and solidification of roots of lithosphere (Ostřihanský 1983). The asthenosphere behaves like a liquid, it enables to oceanic lithosphere to drop down by gravity to the depth being dissolved in $600 \mathrm{~km}$ depth and the alternating movement of the whole mantle during alternating rotation velocity of the Earth. Considering the mantle with its large mass subjected to variable deceleration and acceleration given by the Mf fundamental lunar wave with a period of 13.66 days and the Mtm long-period tidal wave with a period of 9.13 days reflecting LOD (length of day) variations, this is a factor which stirs the lithosphere driven by tidal friction towards west (Fig. 5). The shaking plates move like a pneumatic hammer through the mantle, its variable energy is enormous $7.42 \times 10^{20} \mathrm{~J}$ (Varga et al. 2005).

Calculation of this variable torque is following, coming from the motion equation of the rotating body:

$$
\mathrm{M}=\mathrm{J} \varepsilon
$$

where $\mathbf{J}$ is the moment of inertia and $\varepsilon$ is acceleration. The mantle moment of inertia is

$$
\mathrm{J}=\frac{2}{5} m_{1} r_{1}^{2}-\frac{2}{5} m_{2} r_{2}^{2}
$$

where $m_{1}$ and $m_{2}$ are masses of the mantle and core, $r_{1}$ and $r_{2}$ are corresponding radiuses of mantle $6,078 \mathrm{~km}$ and core $3,478 \mathrm{~km}$. Considering the Earth's mass $5.98 \times 10^{24} \mathrm{~kg}$ and the mass of the mantle $67.5 \%$ and he core $32.5 \%$ of the Earth's mass, then $m_{1}=4.036 \times 10^{24} \mathrm{~kg}$ 

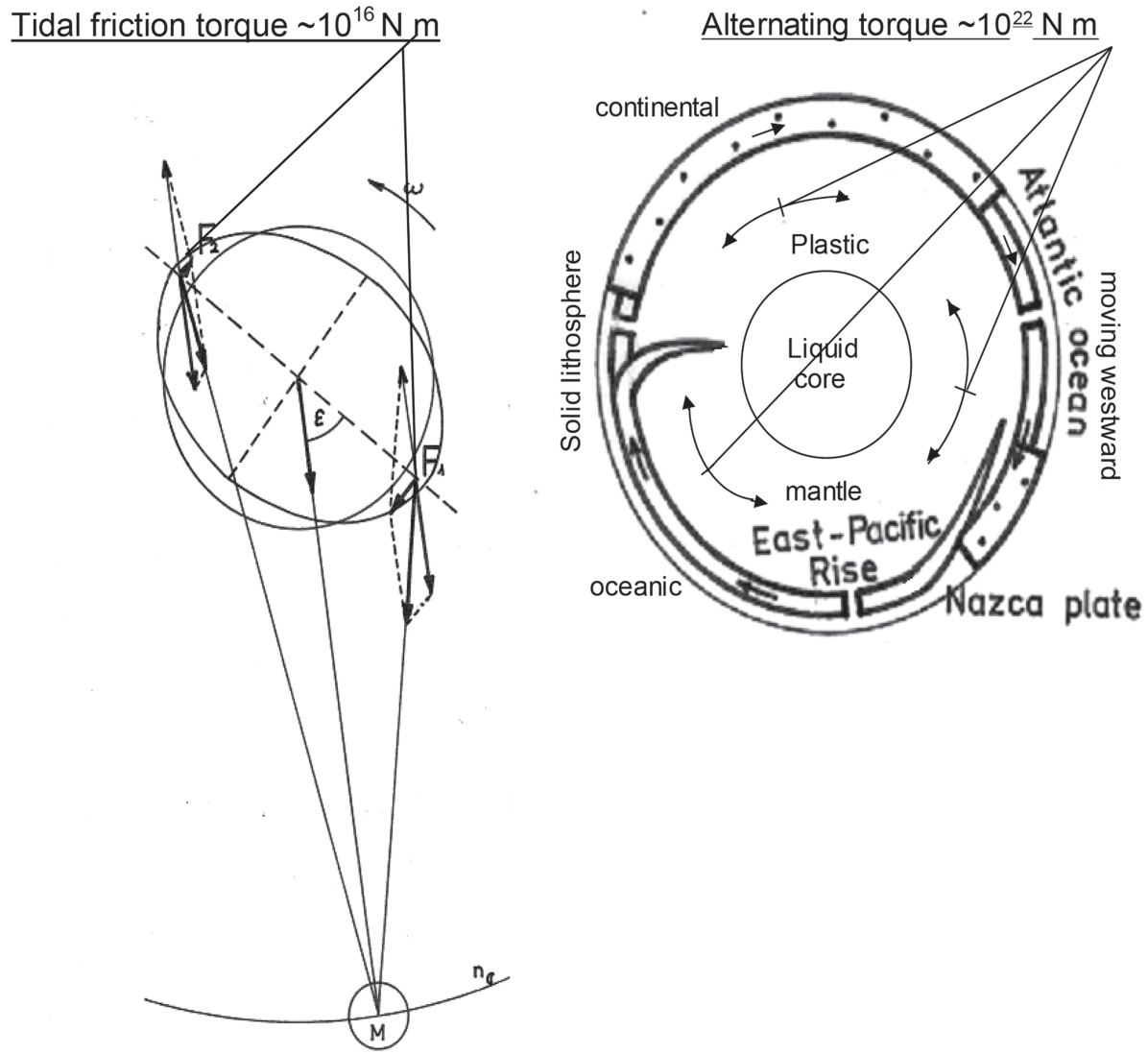

Fig. 5 The explanation of the westward movement is more complicated. The torque exerted by tidal friction is low, always considered as insufficient for the plate movement. Calculation of the torque exerted by Mf and Mtm LOD frequency owing to large amount of the whole mass of mantle gives again large value reaching $10^{22} \mathrm{~N} \mathrm{~m}$. Alternating torque beneath lithosphere and tidal friction kept in rotation frame with the Moon's orbit facilitate the movement of lithosphere westward. Many examples show how body could slide only after shaking

and $m_{2}=1.941 \times 10^{24} \mathrm{~kg}$. After calculation $\mathrm{J}=5.01 \times 10^{37} \mathrm{~kg} \mathrm{~m}^{2}$. If $1 \mathrm{~ms}=0.015^{\prime \prime}$, and the maximum amplitude of Earth's rotation is $1.5 \mathrm{~ms}$ then the corresponding arc is $0.0225^{\prime \prime}$. It takes to shaking Earth for 6.83 days. The acceleration $\varepsilon=0.0225^{\prime \prime} / 5.90110^{5} \mathrm{~s}^{2}=3.806 \times$ $10^{-11 \prime \prime} / \mathrm{s}^{2}=1.845 \times 10^{-16} \mathrm{rad} / \mathrm{s}^{2}$ and $\mathrm{M}=\mathrm{J} \varepsilon=5.0110^{37} \times 1.84510^{-16}=9.24 \times$ $10^{21} \mathrm{~N} \mathrm{~m}$.

The northward tide acts on upper side of lithosphere, on $10 \mathrm{~km}$ bulging caused by the Earth's rotation by the torque $1.8 \times 10^{22} \mathrm{~N} \mathrm{~m}$. The westward tide acts on the bottom of lithosphere by alternating torque $9.24 \times 10^{21} \mathrm{~N} \mathrm{~m}$ in rhythm of LOD. This alternating torque moving with continental lithosphere has been proven by sensitive strainmeters (Milyukov et al. 2012). There is no sense to seek gliding surface for lithosphere over mantle (low velocity zone LVZ). It might exist beneath oceanic lithosphere, but continents have deep roots (over $300 \mathrm{~km}$ ) and such thickness of LVZ was not observed. By LOD variations the mantle is deformed negligibly, considering low Reynods number $<0.5$, but because it is the deformation of enormous volume of the mantle carrying lithosphere subjected to torque of 
tidal friction $10^{16} \mathrm{~N} \mathrm{~m}$, the difference occurs between mantle and lithosphere at least $1 \mathrm{~mm}$ every sidereal week (6.86 days) and 52 weeks give $5 \mathrm{~cm}$ of year's westward drift corresponding to reality. If a large amount of oceanic lithosphere drops down by gravity to subduction zone (case of M 8.8 Offshore Maule Chile 27 February 2011) then alternating mantle can tear large belt of lithosphere ranging from Concepcion on Pacific coast (GPS movement 3.04 $\mathrm{m}$ westward) to Buenos Aires on Atlantic (GPS movement 2-4 cm westward) in width as far as Chilean border with Peru. (GPS measurement of Mike Bevis group, Ostřihanský 2012a.)

At the end of this paragraph let us mention the tidal force acting in vertical direction, which therefore cannot move plates but is easily observable on the Earth's surface uplifting the solid Earth twice in a day for several decimeters and oceans for $1 \mathrm{~m}$ maximum, regardless coastal and resonant effects of seas uplifting waters as far as $20 \mathrm{~m}$. This force does not create torques, only creates stress $\sim 10^{3} \mathrm{~Pa}$ (Bodri and Izuka 1989), but because acting twice in a day for millions of years, it creates by the fatigue of lithosphere the most significant tectonic features on the Earth the mid-ocean ridges roughly of meridional direction, recently manifested by the Mid-Atlantic ridge and the East Pacific Rise. These originally meridional tectonic faults (from those non-opened as mid-ocean ridges let us name e.g., Rhine graben, Ninety East ridge, Ural+Novaya Zemlya, East African rift+Red Sea etc.) reached deeply to polar regions (Fig. 8), because they converge to poles they contributed significantly to the break-up of Gondwana on the south pole particularly by the release of S. America+Africa and facilitated the movement of plates driven by the northward directing tidal force out of equator (see further text).

\section{Description of northward and westward action of tidal forces on movement of plates and confirmation of movements by hotspot tracks}

The northward movement of plates caused by tidal forces acting on $10 \mathrm{~km}$ bulging caused by the Earth's flattening are manifested by the most effective changes of the Earth's surface and by this movement the highest mountains on Northern Hemisphere were created (Figs. 6, 7).

The example of the northward movement represents the movement of the Pacific plate; by this movement the high mountain was created, the Alaska Range. The Hawaii-Emperor Seamount Chain is the best developed hotspot track on the Earth and exactly describes the movement of the Pacific plate. The oldest northward directing part of the chain describes the northward motion of the Pacific plate forming the second highest mountains on Northern Hemisphere the Alaska Range Mountains. When the western part of the Pacific plate became older and dropped down to mantle by gravity then the Pacific plate moved in NW direction driven by both two components of the plate movements northward and westward (Fig. 9). Instead of it mantle convection supporters complicated imaginations introduce about hypothetical plates Kula and Izanagi in spite that effects contradicting to the mantle convection in Pacific has been presented long time ago (Sandwel and Renkin 1988).

In Atlantic Ocean many hotspots are interrupted by the Mid-Atlantic ridge. Such case is the New England Seamount Chain (NES Fig. 7), which has a continuation as a fixed hotspot close to African coast (CAN on Fig. 7, connected by dashed line). Similarly by the movement of hotspot from Baffin Bay beneath Greenland to the stable position in Mid-Atlantic ridge the Icelandic hotspot was created (Fig. 10).

Hotspots are not absurd bodies created on the core-mantle boundary but bodies relatively shallow situated beneath lithosphere because from the mantle bottom the solid xenoliths could not be delivered to the Earth surface. Hotspot tracks formations and their behavior approaching the mid-ocean ridges moving with average speed of adjacent plates, are described 
a

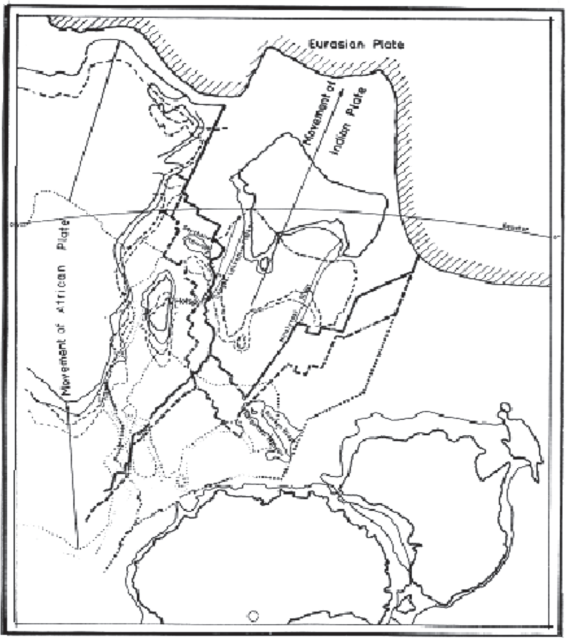

$\mathbf{b}=1 \ldots$

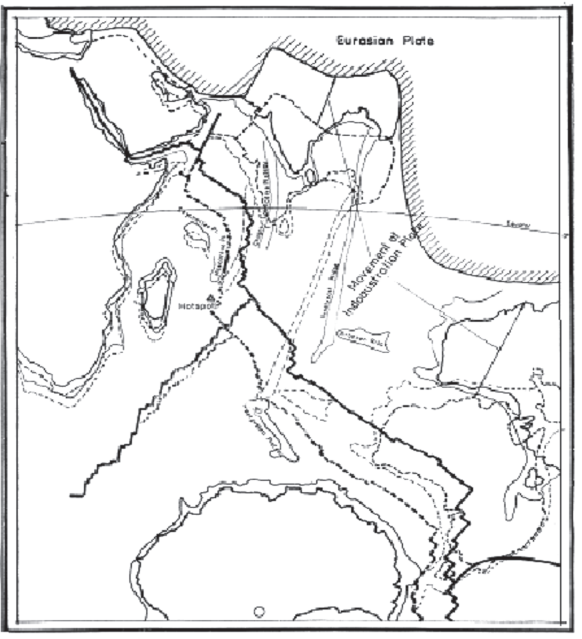

:=:: $37 \mathrm{Mr}$ = Present

Fig. 6 Shows the northward movement of the Indian Ocean. The African plate performed the oldest movement, then the narrow oceanic plate moved with Indian Peninsula behind, pushing the whole oceanic lithosphere in front of the Indian Peninsula to the subduction zone in Laurasia, later in Eurasian plate and created the highest Earth's mountains Himalayas (Ostřihanský 1990)

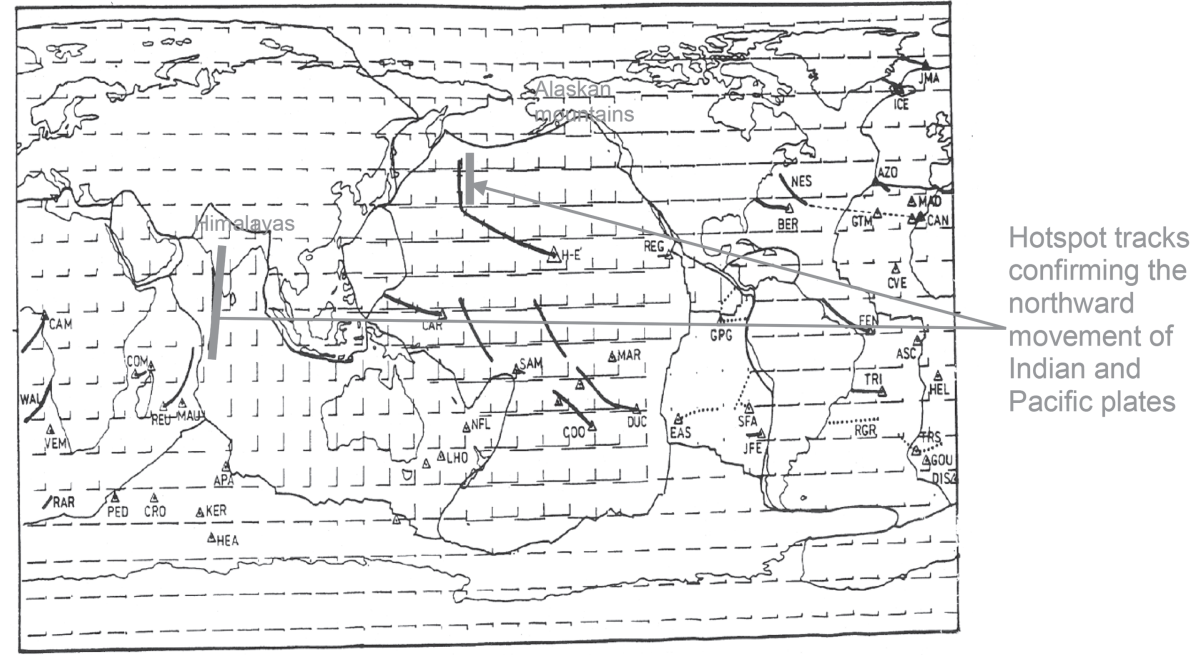

Fig. 7 The movements of the Indian and the Pacific plates are exactly documented by the hotspot tracks. The northward movement the Reunion hotspot documents, interrupted by the Southwest Indian Ocean ridge. The northward movement of the Pacific plate the northern part of the Hawaii-Emperor Seamount Chain documents exactly, till the NW movement of the Pacific plate when on its western rim the deep subduction zone was created owing to oceanic lithosphere, which grown old and dropped down to mantle by gravity

in Ostřihanský (1997). When the hotspot reaches the mid-ocean ridge is uplifted and remains fixed in the new plate. There are three types of hotspot tracks formation in African, American and Indian plates (Fig. 11). 
Fig. 8 Proves the westward movement of lithosphere. The oldest and the most distant parts of the Atlantic ocean drops down to mantle by gravity and the subducted oceanic lithosphere is pushed by the rolling mantle. The same case the Caribbean plate represents in low latitudes. The Figure shows also the consequent decay of Gondwana equivalent to Fig. 6
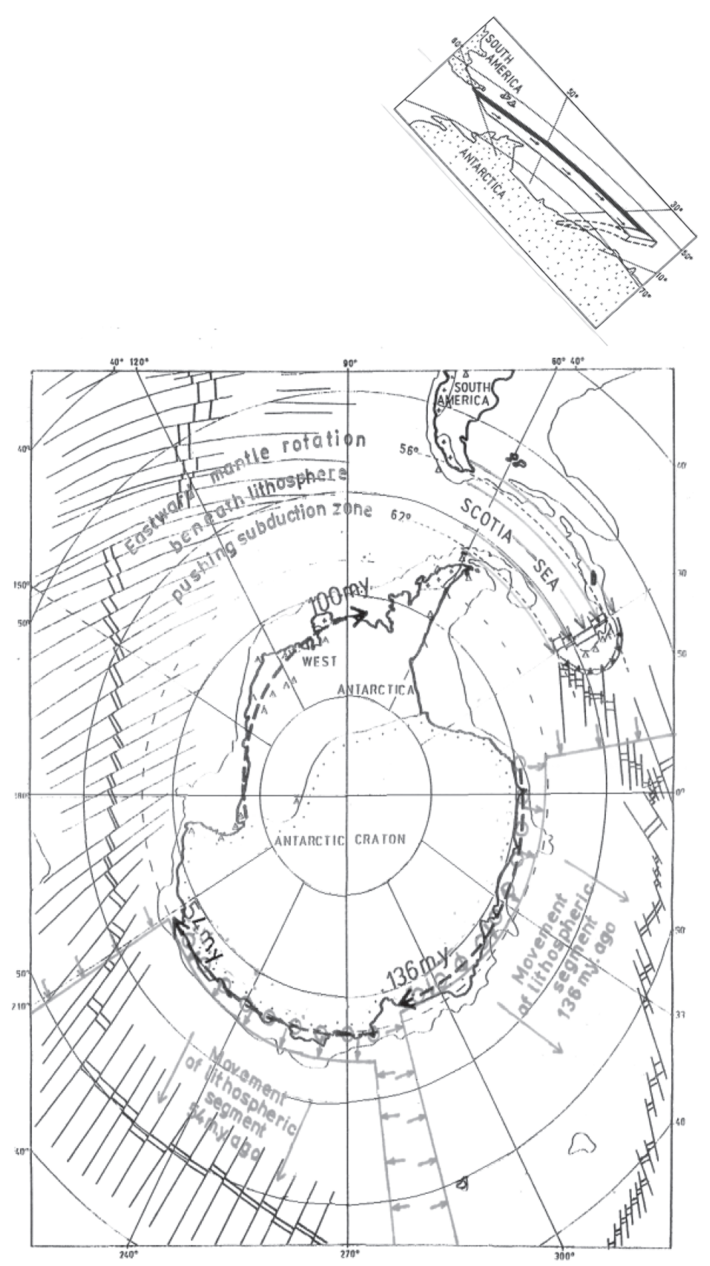

In 1971, Morgan provided the plume theory as an explanation for volcanic inconsistencies. This hypothesis suggests that hotspots are underlain by narrow upwelling plumes which originate from the core-mantle boundary (CMB). Allen et al. (2002) and Montelli et al. (2004) have used a range of seismological techniques to further this theory, and came to the conclusion that the Iceland plume can clearly be resolved only in the upper-mantle. Low velocity anomalies have been detected within the mantle under many hotspots; however there is still dispute over whether they can be called plume structures. Certain scientists do not accept them as plumes since they do not exactly fit the deep-mantle plume model and have developed new theories. David Bercovici is one of the greatest mantle convection supporters. His detailed description of the plate movement by mantle convection (Bercovici 2010) is not convincing for me as for many others in the past. Jeffreys (1974) argued that convection cannot take place because it is a self-damping process, as described by the Lomnitz law. Recently Pratt (2000, 2013). Kalenda et al. (2011) and Herndon (2005, 2013) presented convincing arguments against mantle convection. My contribution is: I presented proof that lithospheric plates move exactly in directions corresponding to tidal forces as next description confirms: 


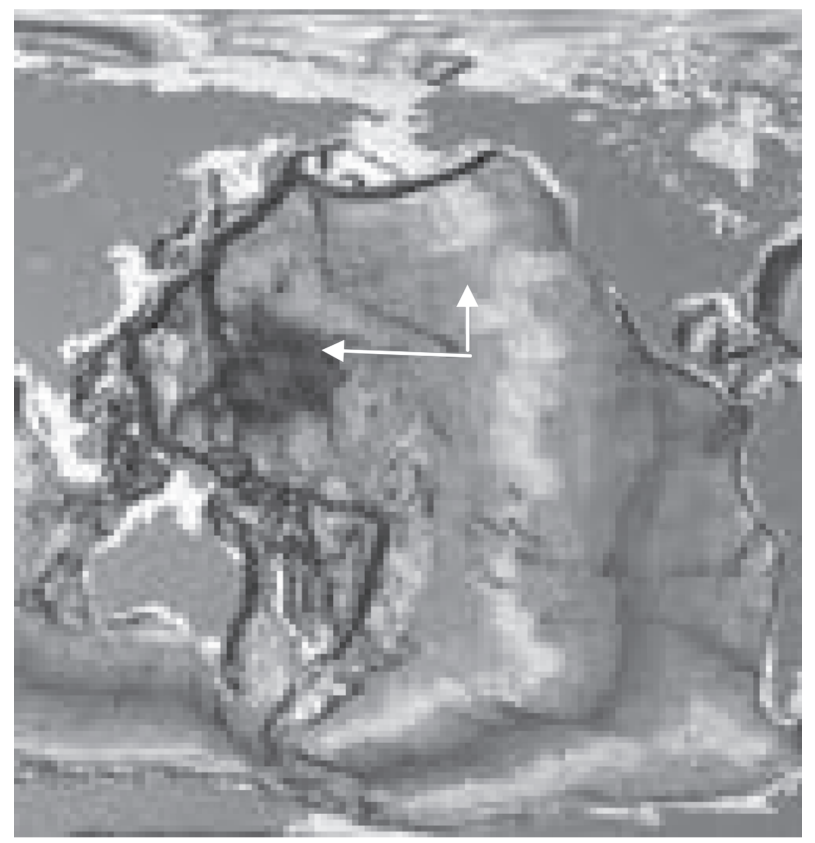

Fig. 9 The present direction of the Hawaii-Emperor Seamount Chain well documents the dual character of lithospheric movements. The westward component, working according to Fig. 5 by its variable mantle shaking, creates the sea-floor spreading in the East Pacific rise. The northward component, working according Fig. 4, by its strong torque pushes the whole plate to Aleutian subduction zone, created in geological past the Alaskan mountain range

Fig. 10 Shows the long travel of the Icelandic hotspot as far as its uplift in the Mid-Atlantic ridge (Ostřihanský 1997)

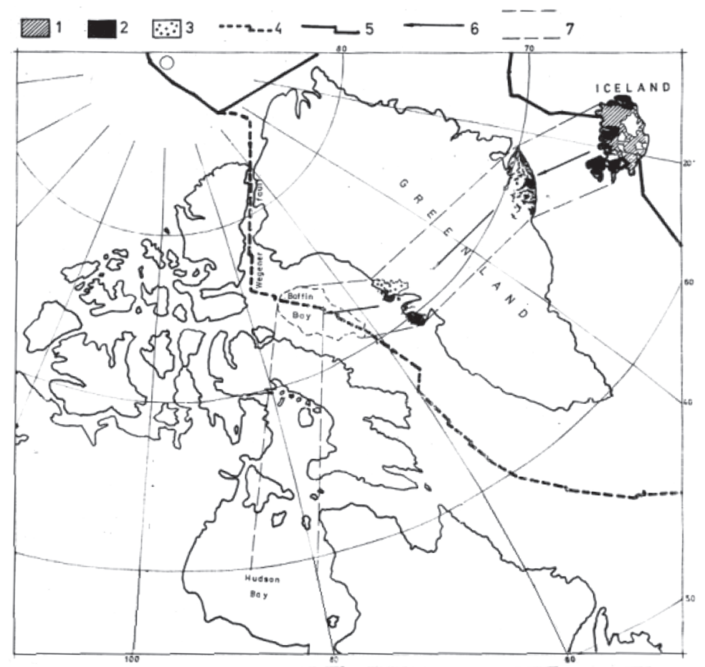

As far as the papers of Montelli et al. $(2004,2006)$ is concerned, she and her colleagues depict many of hotspots (Hawaii hotspot including) reaching the lowermost mantle in many cases as far as CMB. However it is evident that this phenomenon weakens dropping down and in many cases extinct before reaching $\mathrm{CMB}$ where therefore cannot be created. A hypothesis is offered 
a

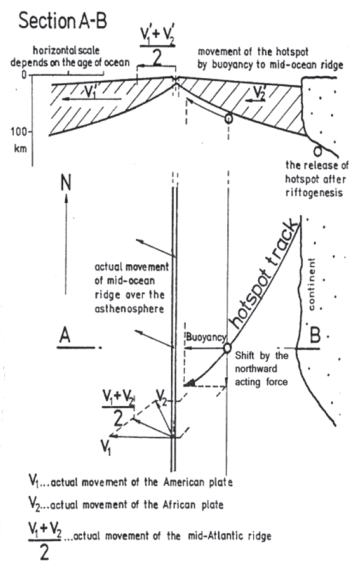

Hotspot tracks from west African coast are result of the uoyancy, forcing hotspots to mid-Atlantic ridge and the orce following from the Earth's flattening, which shifts the plate to the north. Buoyancy influences the hotspot namely the beginning of the ocean opening when the lithosphere -asthenosphere boundary is steep. The midatlantic ridge bottom cause that hotspots mostly do not reach the midocean ridge. The hotspot cannot move backward to the

Fig. 11 Shows the formation of hotspot tracks in different conditions of northward or westward moving plates (Ostřihanský 1997)

that the light plume's material by buoyancy rises upwards and the heavy one (e.g., heavy iron containing material considering the meteoritic origin of hotspots (Ostřihanský 1997)) drops down by gravity. It is also evident that this phenomenon disqualifies any imaginations about mantle convection.

The northward and southward tidal component of the plate movement describes Fig. 12. The map is derived from the no net rotation frame, but the zero point of the plate movement was chosen on northern side of the Nazca plate in coordinates $5^{\circ} \mathrm{S}$ and $90^{\circ} \mathrm{W}$. The Cocos and Nazca plates are small, newly created, and therefore easily drifted by rolling mantle. The Galapagos hotspot stays firmly in the plate, its double hotspot tracks (Carnegie and Cocos) were created during the consequent tearing of Cocos and Nazca plates apart (Ostřihanský 1997). The fossil mid-ocean ridge on the east from the East Pacific Rise presents another proof of the stability of the Nazca plate over mantle as a part lost behind during the quick westward movement of the Pacific plate. The so called Global plate motion 2008 GPS map (Heflin et al. 2007) considers the continental lithosphere fixed in GPS satellite network. This map therefore does not describe the plate movement over mantle, only components of forces in faults created during plates geological past and false enlarged movements of islands in oceans. The real continental lithosphere movement by GPS is evident after large earthquakes (Ostřihanský 2012b).

Figure 13 shows the movement of mid-ocean ridges over mantle. Most of world's hotspots (black points in Fig. 13) are trapped in continental rift zones. They are the West African rift system, East African-Red Sea rift and East Asian rift system. Spotless areas are on oceanic eastern sides of these rift systems.

The shape of back-arc basins confirms also the westward movement. Back-arc basins are on stern side of oceans opened and non-deformed, consequently to the east are deformed and in the eastern side compressed and shifted to the continent (Ostřihanský 1997). American continent overrides the East-Pacific rise as already Tuzo Wilson (1965) claimed. Nevertheless 


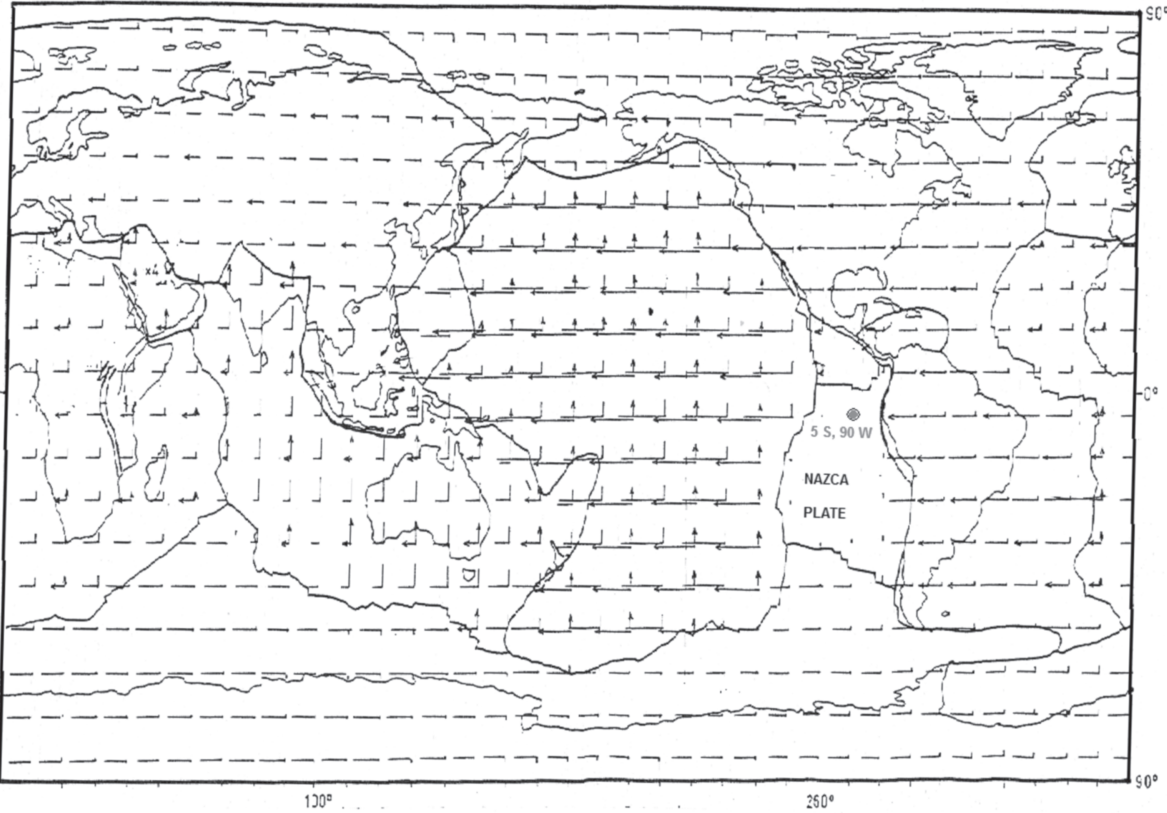

Fig. 12 Shows the real plate movements in 10 M.Y. over mantle. The map is derived from the no net rotation frame, but the zero point of the plate movement was chosen on northern side of the Nazca plate in coordinates $5^{\circ} \mathrm{S}$ and $90^{\circ} \mathrm{W}$ (Ostřihanský 1997)

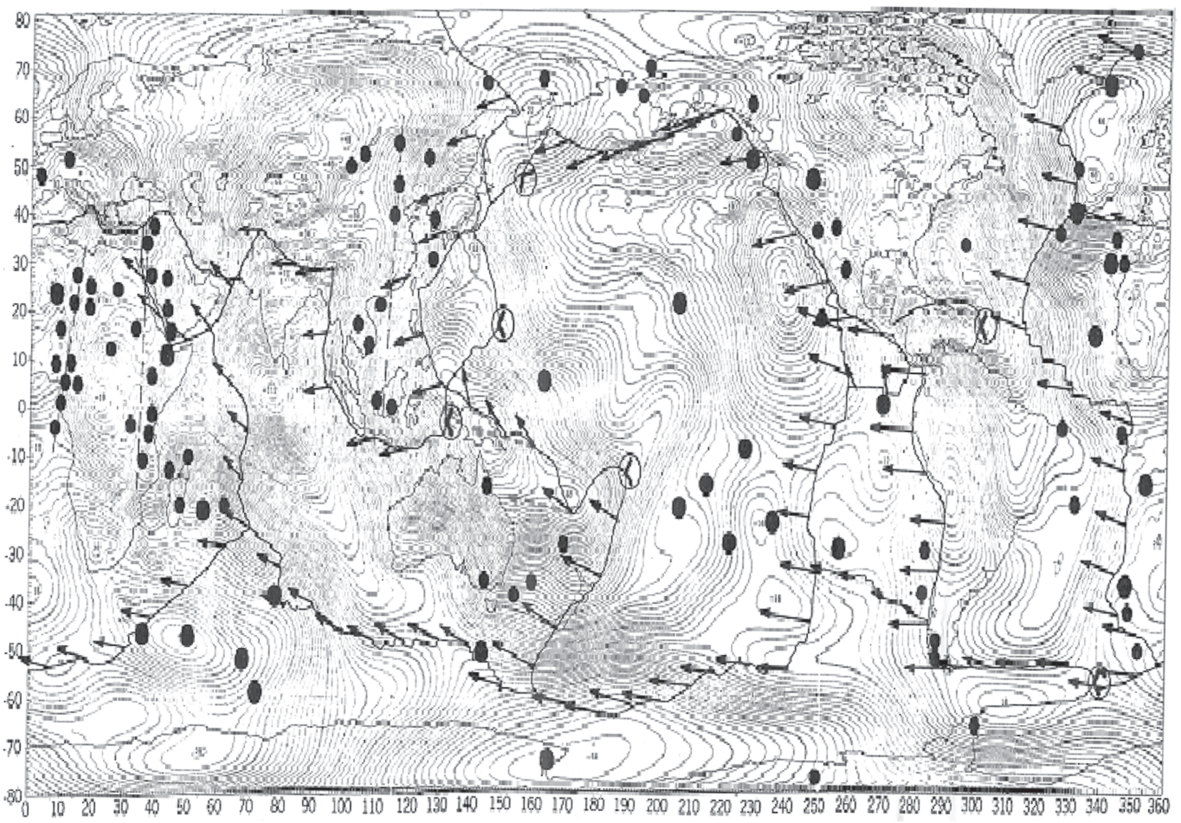

Fig. 13 Shows the movement of mid-ocean ridges over mantle as passive formations moving with the average speed of adjacent plates, creating behind the moving plate the new oceanic lithosphere (Ostřihanský 1997) 
Separation of Gondwana from Laurasia $\mathbf{5 7 0}$ M. Y. ago

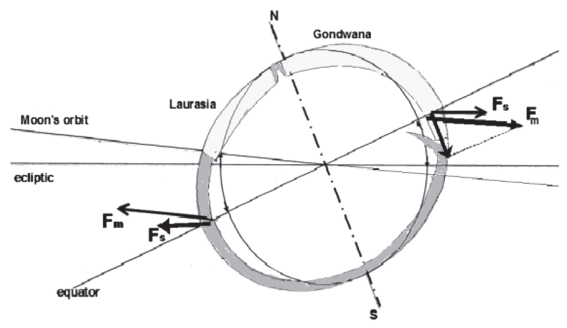

Remark: Against the mid-ocean ridge the component of tidal force is ineffective.

Separation of Africa and South America back north 136 M.Y. ago

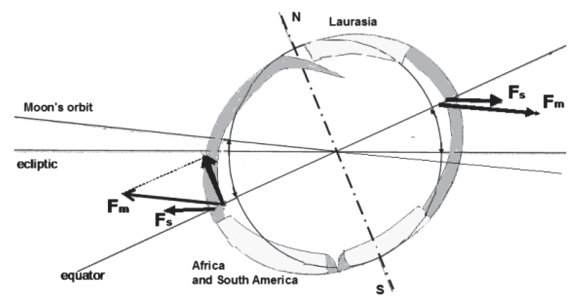

Remark: The figure is mirror reversed against other three figures, i.e. turned for 12 hours for better imagination
Gondwana on South Pole 240 M.

Y. ago

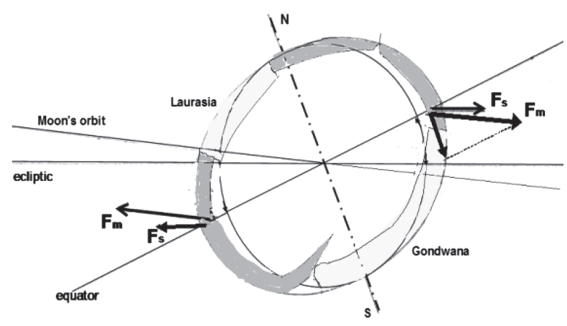

Movement of Indian Peninsula 120 M.Y. and later Australia 54 M.Y. ago

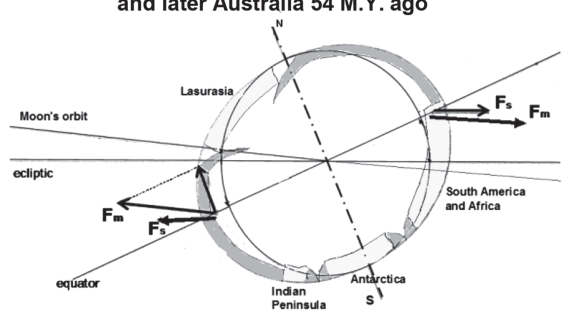

Remark: Antarctica remains out of tidal force action

Fig. 14 The movement of lithospheric plates in N-S direction since the decay of Pangaea 570 M. Y. ago. Fm and Fs are tidal forces from Moon and Sun respectively acting on Earth's flattening. Continents are grey and oceanic lithosphere black (Ostřrihanský 2012b)

the decisive effect on the lithosphere has the tidal force acting on the flattened Earth. Instead of the Polfluchtkraft (flight from the pole force) (Wegener 1915) the Äquatorfluchtkraft (tidal north-south force Fig. 4) acts. This force transferred Gondwana to the South Pole and its decayed parts back to the north. The next Fig. 14 describes and explains this enormous transfer of continental lithosphere:

570 M.Y. ago the old oceanic lithosphere situated on Southern Hemisphere dropped down by gravity and the component of tidal force acting by its center on equator pushed the Gondwana to South Pole. 240 M.Y. ago the Gondwana is situated on South Pole and decays. Because 138 M. Y. ago the old oceanic litosphere in contact with Laurasia dropped down by gravity the tidal force pushed Africa and large Pacific plate northward. 120 M.Y. ago the oceanic lithosphere of today's Indian plate moved northward with small continental Indian Peninsula behind. 54 M. Y. ago Antarctica remained on South Pole being out of action of the tidal force.

Out of action of tidal force remained also Laurasia separated by westward tidal force (according to Fig. 5) on North American and Eurasian plates. By this force also the South America was separated from Africa and because by the northward movement of Africa, only young lithosphere was created on northern side of South America, the absence of subduction zone prevented the northward movement. Very old subduction zone existed on western side of both Americas but it subducted long time ago and these continents today override the young Pacific lithosphere and the North American continent overrides even the East Pacific Rise. 
Fig. 15 Terminal Proterozoic to late Paleozoic apparent polar wander (APW) path for Gondwanaland (Evans 2003). $\mathrm{I}_{\min }$ is the minimum-inertial axis. The figure documents the saw-tooth movement of the lithosphere

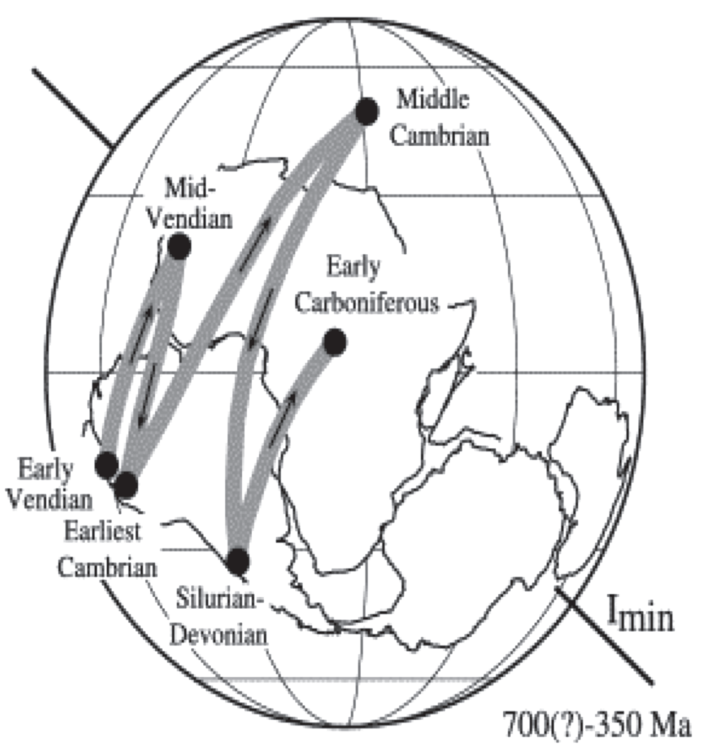

A

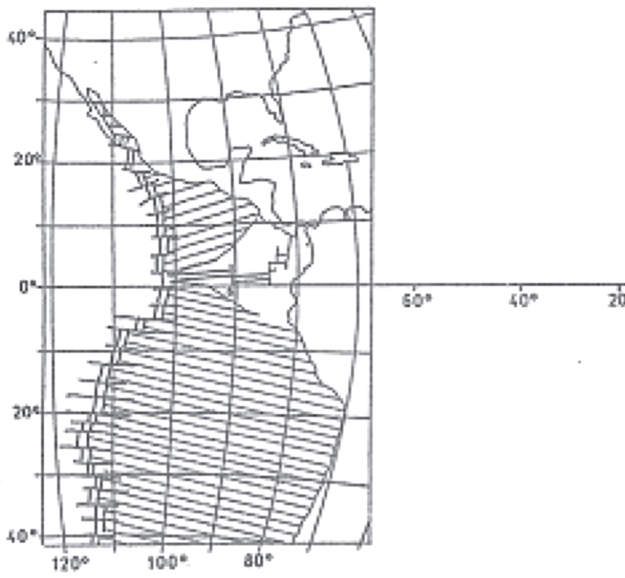

B

Fig. 16 The westward drift can be manifested also by the rupture of narrow bands of oceanic or continental lithosphere, The Cocos-Nazca plates bordered by East Pacific Rise (left) and the Red Sea-East African Rift (right) are examples of small plates left behind in equatorial regions during the westward movement. Small rupture of oceanic lithosphere is also evident in Gibraltar region, which caused the opening of the Mediterranean Sea after its closure (Tertiary Messinian salinity) during Africa Eurasia collision

Calculation of Äquatorfluchtkraft is very important, it confirms the real plate movements in the past (Fig. 14), best evident from the saw-tooth westward movement of Gondwana by apparent pole wander path of Evans (2003) (Fig. 15).

The westward drift can be manifested also by the rupture of narrow bands of oceanic or continental lithosphere in equatorial regions, The Cocos-Nazca plates bordered by East Pacific Rise (A-Fig. 16) and the Red Sea-East African Rift (B-Fig. 16) are examples of small plates left behind in equatorial regions during the westward movement. Small 
Table 1 Astronomical parameters of Sumatra 27. December 1985 and 26. December 2004 earthquakes

\begin{tabular}{lll}
\hline & Sumatra 1985 & Sumatra 2004 \\
\hline Date of earthquake & 27 December 1985 & 26 December 2004 \\
Earthquake magnitude & 6.6 & 9.1 \\
Date of LOD minimum & 28 December 1985 & 26 December 2004 \\
Moon's declination & $27^{\circ} 32^{\prime}$ & $27^{\circ} 41^{\prime}$ \\
Sun's declination & $23^{\circ} 20^{\prime}$ & $23^{\circ} 21^{\prime}$ \\
Date of full moon & 27 December 1985 & 26 December $2004^{\prime}$ \\
Length of ascending node & $35.8235^{\circ}$ & $28.3244^{\circ}$ \\
Date of moon's apogee & 23 December 1985 & 27 December 2004 \\
Date of $0^{\circ}$ ascending. node & 9 November 1987 & 20 June 2006 \\
Maximum moon's declination & $28^{\circ} 42^{\prime}$ & $28^{\circ} 43^{\prime}$ \\
Date of maximum moon's declination & 13 October 1987 & 15 September 2006 \\
\hline
\end{tabular}

\section{Earthquake Sumatra December 26, 2004, M 9.1}
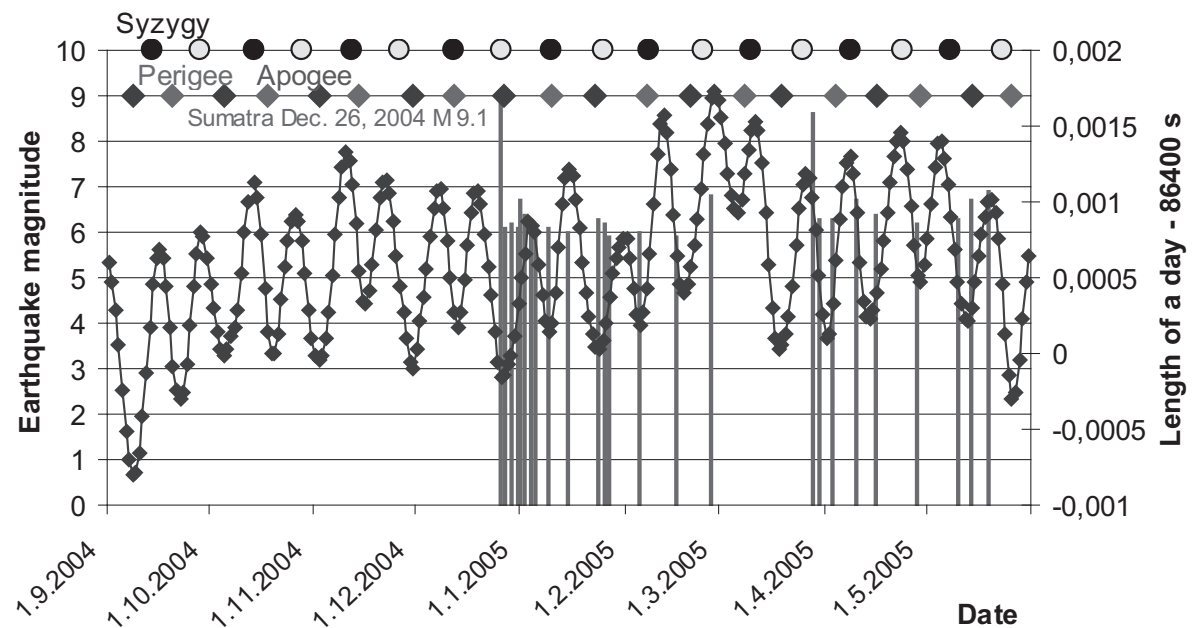

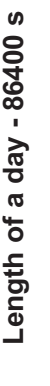

Fig. 17 Earthquake Sumatra December 26, 2004, M 9.1 as repetition of the Sumatra 1985 earthquake after 19 years of Metonic cycle. Concidence of full Moon, LOD minimum and apogee is evident. 5 days difference of winter solstice

rupture of oceanic lithosphere is also evident in Gibraltar region which caused the opening of the Mediterranean Sea after its closure (Tertiary Messinian salinity) during Africa Eurasia collision.

\section{Correlation of tidal forces with earthquakes}

Knowing astronomical causes of lithospheric plates movements, it seems to be that under the same astronomical parameters the same earthquakes occur. Table 1 shows almost negligibly different astronomical parameters of earthquakes Sumatra 26 December 2004, M 9.1 and Sumatra earthquake 27 December 1985 M 6.6. The exact time span 19 years indicates the 
Table 219 years repetition of major Californian earthquakes and their multiples in past 200 years

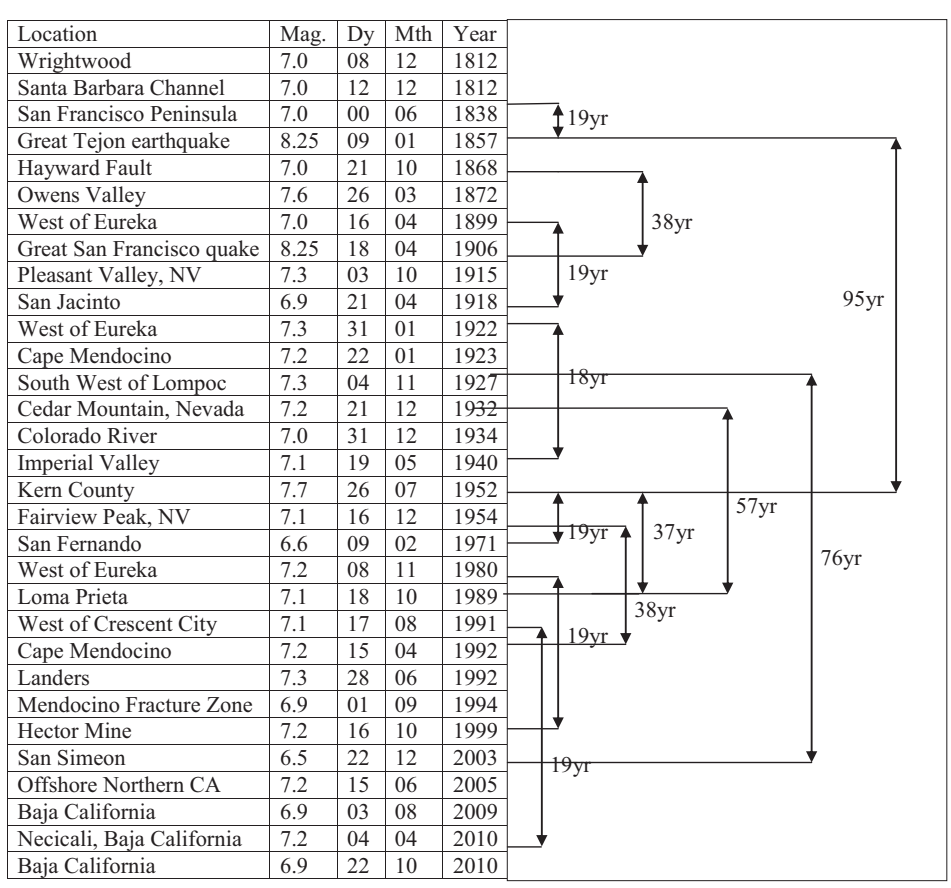

Metonic cycle and Figs. 17 and 18 show the exact positions of full Moon, winter solstice, maximum Moon's and Sun's declination and maximum Earth's rotation speed and similar character of aftershocks. Such position however does not occur every 19 years because maximum torque depends on full Moon and also on maximum Moon's declination varying in 18.61 years nodal cycle. Coincidence both parameters $s=t_{1} \times t_{2} /\left(t_{2}-t_{1}\right)=18.61 \times$ $19 /(19-18.61)=900.6$ yr. One more 19 years earthquake repetition occurred 21 December 2010 M 5.9 and 22 December 1991 M 5.9, because in both cases the Moon's declination was still high. Then during 60 years of LOD measurements back, no such repetition occurred. Nevertheless 19 year earthquake repetition is remarkable for Alaskan earthquakes 1964, 1983 and 2002 (Ostřihanský 12b). The Table 2 compiled on observation of Californian amateurs shows that in the last 200 years many 19 years repetitions or repetitions of multiples of this period had occurred. However these periods are not exact, they differ for several months. The reason of inaccuracies consists in NW movement of the Pacific plate, whereas in Sumatra in December 1985-2004 and 1991-2010 the Indian plate moved directly northward. Earthquakes on Figs. 17 and 18 were created by the northward directing force according to mechanism of Fig. 4. Figure 19 corresponds to different Moon's position in winter solstice 2009. The Sun's position is the same as on Fig. 4 but the Moon is situated on intersection of its orbit with equator. On 23.XII.2009 the Moon exerts no torque on Earth's rotational bulging and therefore the component of force directing the Indian plate northward is equal to zero. Because Sumatra is situated close to equator, small earthquakes 9.XII.2009 and 23.XII.2009 on LOD maximum could be created by strong solid Earth tides. The earthquake Sumatra M 8.6 (Fig. 20) owing to the close position of the Sun on equator 28.3 owing to its vicinity of vernal point and therefore position of the Earth's rotational bulging coinciding with the 


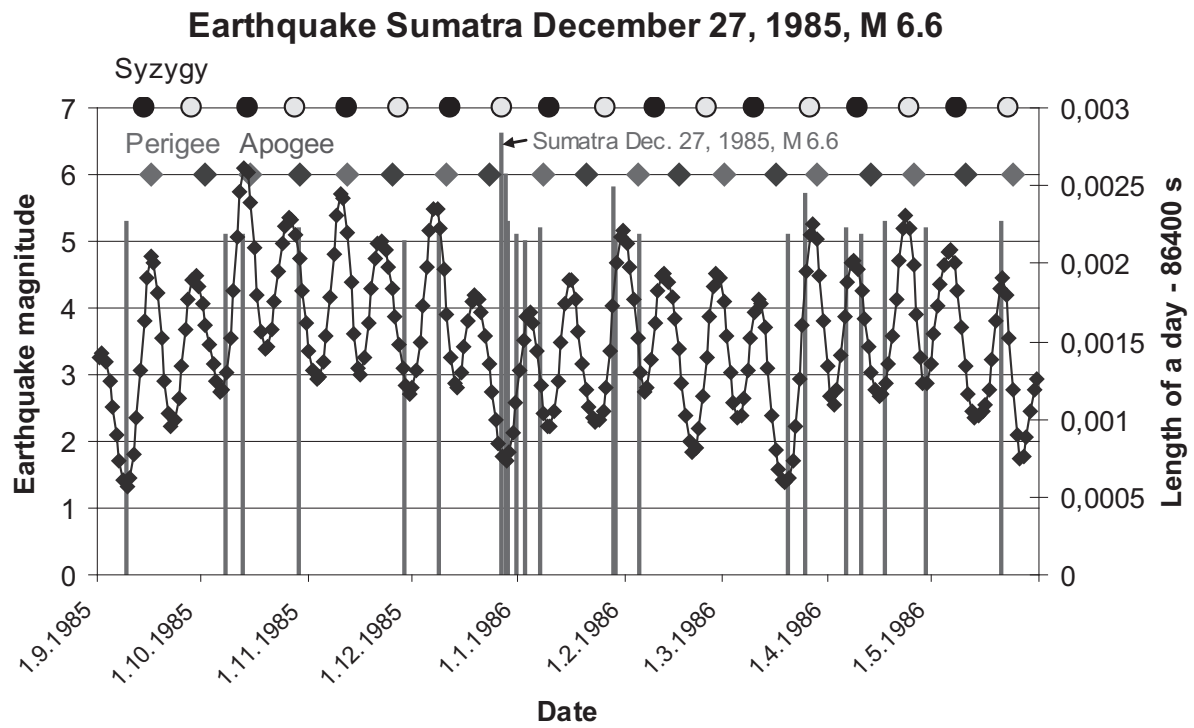

Fig. 18 Earthquake Sumatra December 27, 1985, M 6.6. Coincidence of the full Moon, LOD minimum and small difference between apogee (Dec. 23, 1985) and winter solstice is evident

plane of ecliptic, this earthquake was created according to mechanism of Fig. 5 by the force directing westward. It is evident extreme LOD variations (corresponding to Fig. 5 right) from extreme velocity increment $1.5 \mathrm{~ms}$ to following velocity decrement coinciding with the full Moon and spring tides causing extreme tidal friction (left side of Fig. 5). The whole phenomenon is for 2 days delayed probably by waste flooding after tsunami. Aftershocks repeated with 2 days delay twice in 13.66 (1/2 of Moon's sidereal period) of LOD variations (Fig. 20).

The origin of the plate movements is well recognized but in spite of it the earthquake prediction is still a difficult problem. The handicap consists in reality that the northward and westward forces act perpendicularly and only the resultant gives the maximum pressure. On the other hand these pressures do not act at the same time. This complication arises from different torque variation, for northward drift 12 hours (more exactly $12 \mathrm{~h} 25.2 \mathrm{~min}$ ) and LOD variation in 1/4 of sidereal Moon's orbit 6.83 days. Only coincidence of both times gives the maximum earthquake, but earthquakes can occur in vectorial addition of both torques, i.e. out of maximum or minimum LOD. The westward drift operates in supporting LOD periods 13.66 days and semidiurnal tidal friction. For this reason only coincidence of both pressures gives statistically significant relation of earthquake occurrence forming normally mixtures of tides. Except of this time many earthquakes occur because the one day northward period is more effective than the westward drift. Nevertheless the LOD 13.66 days variations (Fig. 5) are detectable (after semidiurnal variations subtraction) by sensitive strainmeteres (Milyukov et al. 2012) on the Eurasian continent, which is not affected by the north-south plate movement. Pressure variations in north-south direction (Fig. 4) are detectable by tremors variations in diurnal 24 h 50.4 min periods in Cascadia region (Rubinstein et al. 2008).

There are many other factors triggering earthquakes as the isostatic compensation in mountain areas and also heating of continental lithosphere in summer time, which effects the LOD variation itself. In the northward movement of plates there is the change of pressure towards subduction zone and then towards the mid-ocean ridge in half a day period. Precursor 


\section{Earthquakes coinciding with LOD maxima Dec. 9 and Dec. 23, 2009}

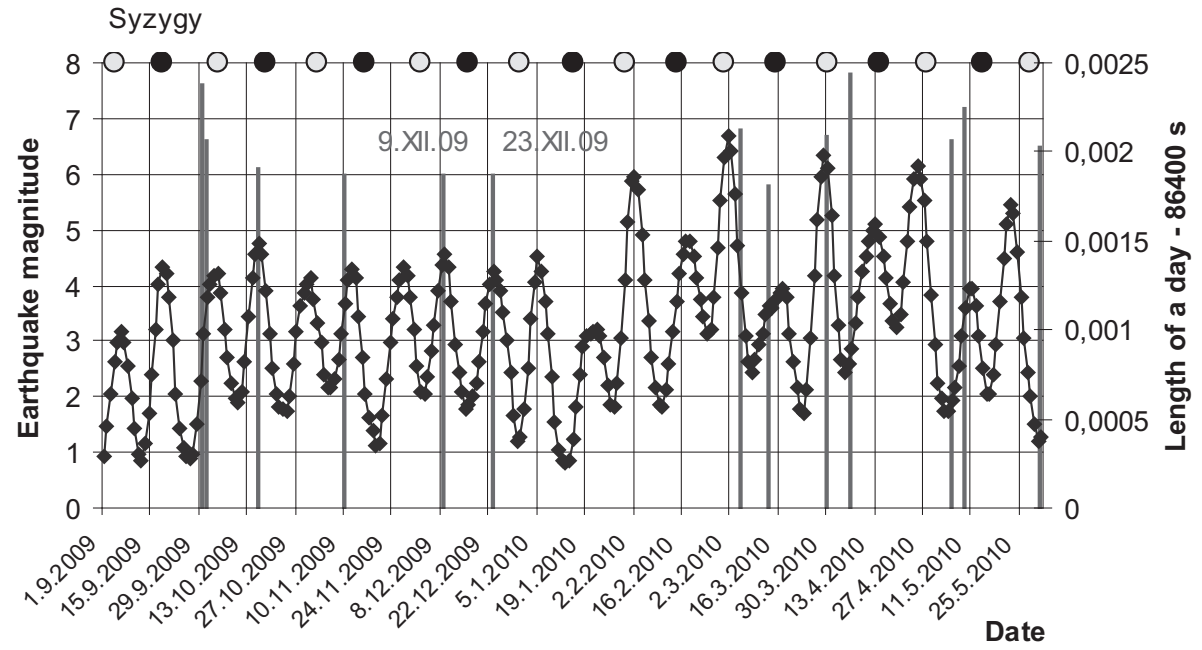

Fig. 19 Shows quite different LOD record from records on Figs. 17 and 18, which is from the same area of the Sumatra and Andaman Sea covering two earthquakes over 5.8 magnitude. Close to the solstice these earthquakes 9.XII.09 and 23.XII.09 coincide with LOD maximums but in the last and first quarters between syzygy. It is evident that only exact repetition of Earth. Moon and Sun position in Metonic cycle can evoke repetition of earthquake

of the Sumatra earthquake occurred in the rear part of the Indian plate in the Southeast Indian Ocean ridge by the strong earthquake M 8.1 in the Macquarie Island $21 / 2$ days before the Sumatra earthquake 26 Dec. 2004 M 9.1. In this case the duplicity of westward and northward tides is also evident. The pressures of westward tides alternate in semidiurnal (6 h $12.6 \mathrm{~min}$ ) periods, whereas the northward tides alternate in diurnal periods ( $12 \mathrm{~h} 25.2$ min), as evident from Figs. 4 and 5. Mixtures of tides give indefinite pressures and indefinite times of earthquakes.

\section{Conclusion}

It is unbelievable how in XXI century conjectures can be accepted about mantle convection, mantle heterogeneities causing movement of plates or even the Earth's expansion. Triple junctions of mid-ocean ridges disprove mantle convection and prove that every plate has its driving force. Rejecting mantle convection we can explain simply and logically all phenomena on the Earth. Dual character of tidal forces directing northward or westward created two mountain ranges (Alps, Himalayas and Alaska range) and (Rocky Mountains and Andes) roughly of perpendicular position. The plate movement is exactly described by the hotspot tracks. The Hawaiian-Emperor Seamount Chain exactly describes the movement of the Pacific plate. Its northward directing oldest part describes the northward motion of the Pacific plate forming the second highest mountains on Northern Hemisphere the Alaska Range Mountains. When the western part of the Pacific plate became older and dropped down to mantle by gravity then the Pacific plate moved in NW direction driven by both two components. Instead of it complicated imaginations about hypothetical plates occur Kula and Izanagi. The development of the Pacific plate is well described by the common action of Earth's rotation 


\section{8.6 Sumatra 28.3.05 earthquake delay}

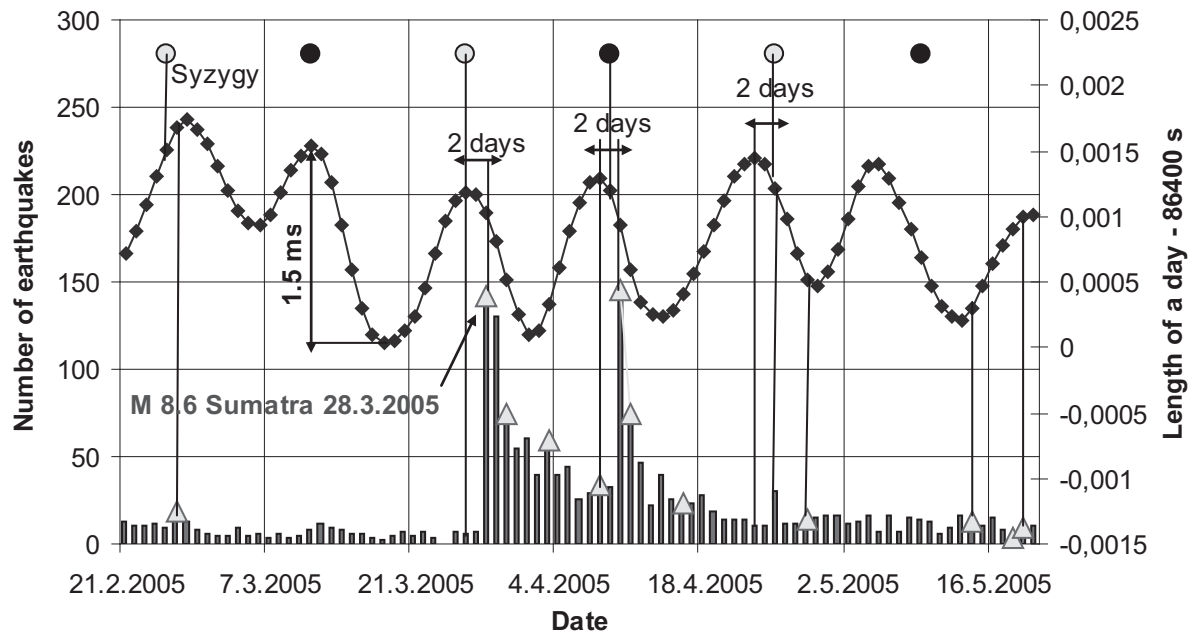

Fig. 20 Whereas earthquakes on Figs. 17 and 18 were created by the northward directing force according to mechanism of Fig. 4, the earthquake Sumatra M 8.6 owing to the close position of the Sun on equator owing to its vicinity of vernal point 28.3 and therefore position of the Earth's rotational bulging coinciding with the plane of ecliptic, this earthquake was created according to mechanism of Fig. 5 by the force directing westward. It is evident extreme LOD variations (Fig. 5 right) from extreme velocity increment $1.5 \mathrm{~ms}$ to following velocity delay coinciding with the full Moon and spring tides causing extreme tidal friction (left side of Fig. 5). The whole phenomenon is for 2 days delayed probably by waste flooding after tsunami. Aftershocks repeated with 2 days delay twice in 13.66 (1/2 of Moon's sidereal period) of LOD variations. Earthquakes M $>5.8$ are marked by triangle

variations, westward drift and the northward tidal action on Earth's rotational flattening (10 $\mathrm{km}$ ). Whereas the sea-floor spreading is created by the westward drift according to Fig. 5 action, the whole by the seafloor spreading created oceanic lithosphere is pushed northward by effective tidal pull on rotational Earth's bulging (Fig. 4). Northward tidal force of torque $1.8 \times 10^{22} \mathrm{~N} \mathrm{~m}$ and westward tidal force of torque $9.24 \times 10^{21} \mathrm{~N} \mathrm{~m}$ exceed tidal friction $\left(10^{16} \mathrm{~N} \mathrm{~m}\right)$ and Eötvös force $\left(10^{13} \mathrm{~N} \mathrm{~m}\right)$ for several orders of magnitude.

Acknowledgments The paper had been exposed as Supplement to the Poster EGU 2013-10877, Geodynamics Session GD1.0, Mon 08 Apr 2013, 17:30-19:00, Blue Posters, B264. Astronomical parameters are from Astronomical Yearbook, Prague observatory. Data for Earth rotation are taken from IERS - Observatoire de Paris Bulletin B, LOD variations, ftp://hpiers.obspm.fr/iers/bul/bulb_new/bulletinb.pdf Data for earthquakes are taken from USGS-NEIC http://earthquake.usgs.gov/earthquakes, ANSS Catalogue http://quake.geo.berkeley.edu/anss/catalog-search.html. ANSS and CMT Catalogue. Plate velocities are calculated in Ostřihanský (1997), stemming from Hager and O'Connel (1980). I very appreciate that the editor Professor Péter Varga invited for the review the most prestigious specialists of the field who expressed very valuable comments. I would like to thank the reviewers for their valuable suggestions, which are an invaluable help for my future work.

\section{References}

Airy GB (1855) On the contribution of the effect of attraction of mountain masses as disturbing during the apparent astronomical latitude of stations in geodetic surveys. Philos Trans R Soc 145:101-104

Allen RM, Nolet G, Morgan WJ, Vogfjörd K, Bergsson BH, Erlendsson P, Foulger GR, (...), Stefánsson R (2002) Imaging the mantle beneath Iceland using integrated seismological techniques. J Geophys Res Solid Earth, 107(B12):2325, doi:10.1019/2001JB000595 
Bercovici D (2010) Encyclopedia of solid earth geophysics. In: Gupta HK (ed) Mantle convection, 1-27, Springer, New York, p 1529

Bodri B, Izuka S (1989) On the correlation between earth tides and microseismic activity. Phys Earth Planet Inter 55:126-134

Bostrom RC (1971) Westward displacement of the lithosphere. Nature 234:536-538

Brož M, Solc M, Durech J (2011) Physics of small bodies of solar system, Charles University, Chair of Astronomy, Prague, irrah.troja.mff.cuni.cz/mira/fyzika_malych_teles/)

Burša M (1987) Secular tidal and non-tidal variations in the earths rotation. Studia geophys et geodet 31: 219-224

Cathles LM (1975) The viscosity of the Earth's mantle. Princeton Press, Princeton

Cochran ES, Vidale TE, Tanaka S (2004) Earth tides can trigger shallow thrust fault earthquakes. Science 306:1164-1166

Dietz RS (1961) Continental and ocean basins evoluted by spreading of the sea floor. Nature 190:854-857

Eötvös L (1913) Verhandlungen der 17. Algem. Konferenz d. Internat. Erdmessungen, Part 1, Astronomische Gesellschaft Hamburg, $111 \mathrm{pp}$

Evans DAD (2003) True polar wander and supercontinents. Tectonophysics 362:303-320

Hager BH, O'Connel RJ (1980) Rheology plate motions and mantle convection. In: Davies PA, Rancorn SK (eds) Mechanism of continental drift an plate tectonics. Academic Press, New York, pp 199-223

Herndon JM (2005) Whole-earth decompression dynamics. Curr Sci 89(10):1937-1941

Heflin BM (2007) Plate motion based on The Global Positioning System (GPS). NASA JPL GPS time series. http://sideshow.jpl.nasa.gov/mbh/series.html

Herndon JM (2013) A new basis of geoscience: whole-earth decompression dynamics. NCGT J 1(2):81-94

Hess HH (1962) History of ocean basins. In: Petrologic Studies: A volume to honor AF Buddington. Geological Society of America, New York

Jeffreys H (1974) Theoretical aspects of continental drift. In: Kahle CF (ed) Plate tectonics-assessments and reassessments (Memoir 23, 395-405). American Associationof Petroleum Geologists, Tulsa, OK

Kalenda P, Neumann L, Málek J, Ostřihanský L, Procházka V, (2011) Tilt, global tectonics and earthquake prediction. SWB London, 247p

Knopoff L, Leeds AR (1972) Lithospheric momenta and the deceleration of the earth. Nature 237:93-95

Kreichgauer PD (1902) Die Äquatorfrage in der Geologie. Steyl: Missionsdruckerei

Lambeck K (1977) Tidal dissipation in the oceans: astronomical, geophysical and oceanographic consequences. Philos Trans R Soc Lond 287:545-594 Ser. A

Lay T, Kanamori H, Ammon CJ, Nettles M, Ward SN, Aster RC, Beck SL, Bilek SL, Brudzinski MR, Butler R, Deshon HR, Ekstrom G, Satake K, Sipkin S (2005) The great Sumatra-Andaman earthquake of 26 December 2004. Science 308:1127-1132

Li X, Kind R, Priestloy K, Sobolev SV, Tilmann F, Yuar X, Weber M (2000) Mapping the Hawaiian plume conduit with converted seismic waves. Nature 405(6789):938-941

Milyukov V, Mironov A, Kravchuk V, Amoruso A, Crescentini L (2012) Global deformations of the Eurasian plate and variations of the earth rotation rate. J Geodyn 70:321-330. doi:10.1016/j.jog.2012.05.009

Montelli R, Nolet G, Dahlen FA, Masters G, Engdahl ER, Hung S-H (2004) Finite-frequency tomography reveals a variety of plumes in the mantle. Science 303(5656):338-343

Montelli R, Nolet G, Dahlen FA, Masters G (2006) A catalogue of deep mantle plumes: new results from finitefrequency tomography. Geochem Geophys Geosyst 7 (11), art. no. Q11007

Moore GW (1973) Westward tidal drag as the driving force of plate tectonics. Geology 1:99-100

Ostřihanský L (1978) The radioactivity of the earth's crust in the area of crystalline rocks in Bohemian Massif and its influence on the terrestrial heat flow. (in Czech with English abstract), Geophysical Institute of Czechoslovak Academy of Science, Prague

Ostřihanský L (1983) The causes of vertical movements of the earth's crust (in Czech). Věstník ÚÚG 58:115120

Ostřihanský L (1990) Tidal and Eotvos forces - main agent of lithospheric plates movement. Paper submitted to Geophys Res Lett, but rejected

Ostřihanský L (1991) Forces causing the movement of plates, poster presented at IUGG XX. General Assembly, Vienna, 11-21

Ostřihanský L (1997) The causes of lithospheric plates movements. Charles University Prague, Chair of geography and geoecology

Ostřihanský L (2004) Plate movements, earthquakes and variations of the earth's rotation. Acta Univ CarolGeol 48:89-98

Ostřihanský L (2012a) Earth's rotation variations and earthquakes of 2010-2011. Solid Earth Discuss 4:33-130 
Ostřihanský L (2012) Causes of earthquakes and lithospheric plates movement. Solid Earth Discuss 4: 1411-1483. doi:10.5194/sed-4-1411-2012 (This paper is easily available in Google inserting "ostrihansky astronomy pdf"

Pratt JH (1855) On the attraction of the Himalaya mountains and of the elevated regions beyond them, upon the plumb-line in India. Philos Trans R Soc 145:53-100

Pratt D (2000) Plate tectonics: a paradigm under threat. J Sci Explor 14(3):307-352 www.scientificexploration. org

Pratt D (2013) Paleomagnetism, plate motion and polar wander. NCGT J 1(1):66-152

Riguzzi F, Panza G, Varga P, Doglioni C (2009) Can earth's rotation and tidal despinning drive plate tectonics? Tectonophysics 484:60-73. doi:10.1016/j.tecto.2009.06.012

Rubinstein JL, La Rocca M, Vidale JE, Craeger KC, Welch AG (2008) Tidal modulation of nonvolcanic tremor. Science 319:186-189

Sandwel DT, Renkin ML (1988) Compensation of swells and plateaus in the north pacific: no direct evidence for mantle convection. JGR 91(B4):275-2783

Scalera G (2003) The expanding earth: a sound idea for the new millennium. In: Scalera G, Jacob K-H (Eds.) Why expanding Earth? INGV Publication Rome 181-232

Stacey FD (1977) Physics of the earth, 2nd edn. Willey, New York

Stavinschi M, Souchay J (2003) Some correlations between earthquakes and earth tides. Acta Geod Geophys Hung 38:77-92

Stein S, Okal A (2005) Speed and size of the Sumatra earthquake. Nature 434:581-582

Storetvedt KM (1997) Our evolving planet. Alma Mater (Fagbokforlaget), Bergen

Storetvedt KM (2003) Global wrench tectonics. Fagbokforlaget, Bergen

Varga P, Gambis D, Bizouard Ch, Bus Z, Kiszely M, (2005) Tidal influence through LOD variations on the temporal distribution of earthquake occurrences. Proc. Journées, 2005 - Systèmes de reference spatio temporels. Warsaw, Space Research Centre Polish Academy of Sciences

Varga P, Denis C (2010) Geodetic aspects of seismological phenomena. J Geod 84:107-121

Wegener A (1912) Die Entstehung der Kontinente und Ozeane. Geol Rundsch 3:276-292

Wegener A (1915) Die Entstehung der Kontinente und Ozeane. Friedr. Vieweg \& Sohn, Braunschweig

Wegener A (1929) (tanslated and reprinted 1966).The origin of continents and oceans. New York. Dover

Wilson JT (1965) Submarine fracture zones, aseismic ridges and the International Council of Scientific Unions line: proposed western margin of the East Pacific ridge. Nature 207:907-911 